\title{
To great St Jaques bound: All's Well That Ends Well in Shakespeare's Europe
}

\section{Richard Wilson}

\section{(QpenEdition \\ 1 Journals}

\section{Electronic version}

URL: http://journals.openedition.org/shakespeare/847

DOI: $10.4000 /$ shakespeare.847

ISSN: 2271-6424

Publisher

Société Française Shakespeare

\section{Printed version}

Date of publication: 1 November 2005

Number of pages: $273-290$

ISBN: 2-9521475-1-5

\section{Electronic reference}

Richard Wilson, «To great St Jaques bound: All's Well That Ends Well in Shakespeare's Europe », Actes des congrès de la Société française Shakespeare [Online], 22 | 2005, Online since 01 January 2007, connection on 01 May 2019. URL : http://journals.openedition.org/shakespeare/847 ; DOI : 10.4000/ shakespeare.847 


\section{Shakespeare et l'Europe de la Renaissance}

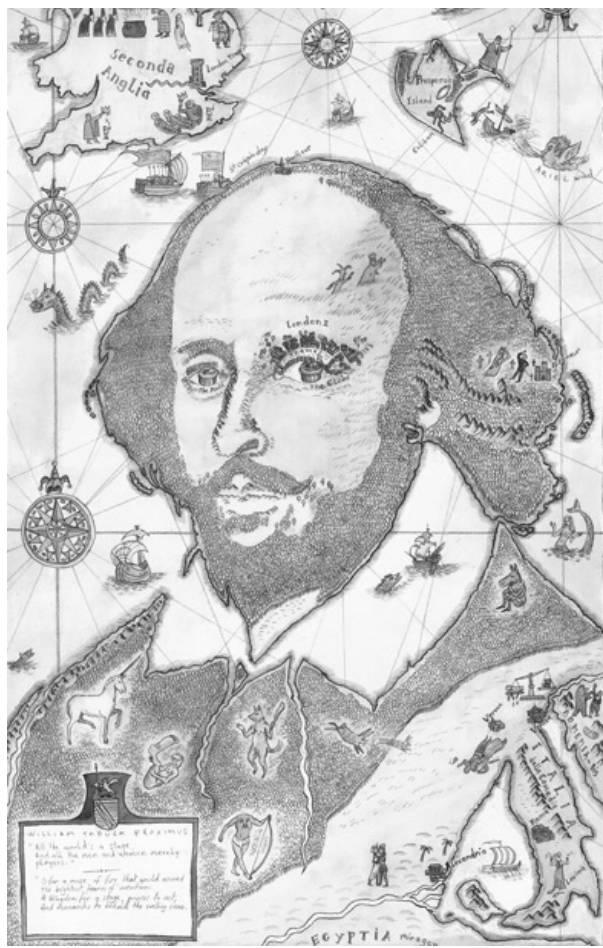

a ctes du Congrès

organisé par la

SOCIÉTÉ FRANÇAISE SHAKESPEARE

les 11,12 et 13 mars 2004

textes réunis par

Pierre KAPITANIAK

sous la direction de

Yves PEYRÉ 


\title{
COMITÉ SCIENTIFIQUE :
}

\author{
Margaret Jones-Davis \\ Jean-Marie Maguin \\ Yves Peyré \\ Pierre Kapitaniak
}

COUVERTURE :

Edouard Lekston, William Tabula Proximus, 2004

conception graphique et logo

Pierre Kapitaniak

CC 2004 Société Française Shakespeare

Institut du Monde Anglophone

Université de Paris III - Sorbonne Nouvelle

http:// univ-montp3.fr/SFS/

5 rue de l’École de Médecine

75006 Paris

ISBN 2-952 1475-1-5

Tous droits de traduction, de reproduction et d'adaptation réservés pour tous les pays 


\title{
TO GREAT S T J AQUES BOUND: ALL'S W ELL THAT ENDS W ELL IN SHAKESPEARE'S EUROPE
}

\author{
Richard WILSON
}

I am Saint Jaques' pilgrim, thither gone": at the turning-point of All's Well That Ends Well (II.iv.4) the heroine, Helena "the daughter of Gerard de Narbonne" (I.i.33), writes to her motherin-law, the Countess of Rousillon, to tell her that instead of staying in Perpignan, she is taking the pilgrim road - El Camino - across Navarre and the Pyrenees to Pamplona, and by way of Burgos and Leon, to the greatest of Europe's Catholic shrines at Compostela. Helena's announcement astonishes the old lady, who declares that "Had I spoken with her, / I could have well diverted her intents" (III.iv.20-1); and with good cause, since this is the only time in Shakespearean drama that a character declares an intention to go to Spain. It is true that the province of Roussillon was itself in Spanish hands when All's Well was written around 1604, and would remain so until 1659; and that for a supposedly patriotic Englishman the dramatist had a provocative trick of setting happy endings in Habsburg territories of the Mediterranean, Belgium and the Holy Roman Empire. But in The Two Gentlemen of Verona "the Imperial's court" (II.iii.4) is never quite connected with Spain, despite the boys joining a party "journeying to salute the Emperor" led by one Don Alfonso (I.iii.39-41); in Much Ado About Nothing Don Pedro's army seems more at home in Sicily than Aragon; in As You Like It the exiles perhaps flee to the Warwickshire Arden rather than the Ardennes of the colleges sponsored by Philip II; in Twelfth Night Illyria floats free from the Adriatic coast coveted by the Habsburgs; in Measure for Measure Vienna is spared Hispanic fanaticism; in The Winter's Tale Bohemia is as much a haven for refugees harried north by Inquisition politics as it was under Rudolf II; and in The Tempest Milan is restored to its rightful ruler in defiance of the fact that in reality it was also to stay Spanish for another fifty years. In The Merchant of Venice Belmont laughs at the Prince of Aragon as "a blinking idiot" (II.ix.54); while in Love's Labour's Lost, Navarre 
mocks that "refined traveller of Spain" (I.i.161) Don Armado, whose penance "enjoined him in Rome" is to wear his mistress's dishcloth "next to his heart" (v.ii.695-8). And it seems no accident that the Don is so absurdly devoted to a girl called Jaquenetta. When Helena claims to have set off barefoot to do penance for her sins on a pilgrimage "To Saint Jaques le Grand" (All's Well, III.v.31), her "zealous fervour" (III.iv.11) therefore appears to open an approach that is unique in Shakespeare, to the Spanish heartland of the Counter-Reformation:

I am Saint Jaques' pilgrim, thither gone.

Ambitious love hath so in me offended

That barefoot plod I the cold ground upon

With sainted vow my faults to have amended.

(III.iv.4-7)

Shakespeare's Europe, as Walter Cohen observes, is exhaustive, since "if references to towns, regions, rivers, and products are included, one comes across Iceland, Ireland, England, Scotland, Lapland, Norway, Denmark, Holland, Belgium, Flanders, Brabant, France, Navarre, Burgundy, Brittany, Normandy... Germany, Italy, Rome, Russia, Poland, Bohemia, Austria, Hungary, Pannonia, Transylvania, Thrace, Macedonia, Illyria, Dalmatia... Greece, Sardinia, Sicily... Crete, Thasos, Lesbos, Rhodes, Cyprus, Turkey... the Canary Islands, Madeira, and Portugal". ${ }^{1}$ And it is this very exhaustiveness that makes Spanish settings such a conspicuous absence from Shakespeare's stage. Which is to say that the Europe Shakespeare represents is split by the same iron curtain as the fractured continent of his day. Spain is out of bounds to Shakespeare's characters because the most important fact of Counter-Reformation Europe was the sectarian wall that cut the pilgrim ways connecting Britain to Iberia and the shrine of Saint James. For as Diarmaid MacCulloch relates in Reformation: Europe's House Divided, until Shakespeare's childhood it was "the pilgrimage routes which continued to unite Europe by sea and land". Thus, in England, Bristol was a "national departure point for the Apostle's shrine on the Spanish Atlantic coast, and pilgrims sailing from the port would be able to enjoy the devotion to Saint James maintained in the

\footnotetext{
${ }^{1}$ Walter Cohen, "The undiscovered country: Shakespeare and mercantile geography," in Marxist Shakespeares, ed. Jean Howard and Scott Cutler Shershow (London: Routledge, 2001), 132-3.
} 
city-centre church". ${ }^{2}$ A sea-passage from Bristol to Galicia took five days; but the fourteen-day land journey across France, under auspices of the Cluniac monks, was preferred by penitents, as Helena suggests, keen to expiate sins by undergoing a more punishing ordeal. So, for five centuries it was the multitudes on the "Great Road" of St James who fused Europe into a single narrative that "transcended while affirming local allegiances": from Reading, where the hand of the saint brought back from Compostela by Queen Matilda was preserved; or Slovenia, where his pilgrims went tax-free; to Saragossa, where it was said the Virgin had appeared to him upon a pillar. ${ }^{3}$ Even in the sixteenth century, Fernand Braudel reminds us, the road to Spain from Paris down the Rue St-Jacques was still "the most active thoroughfare of France". For "while trips to Jerusalem and Rome became a privilege of the wealthy, penitents continued to wend to Compostela" in such numbers that, according to John Hale in The Civilization of Europe in the Renaissance, this era marked "the high-point of cosmopolitanism" - for all but the English. ${ }^{4}$ Thus, when Helena vows to take the Road of the Stars, she is reconnecting the audience with the Europe they have repressed; like that of the palmer of John Heywood's play The Four PP, written in the $1530 \mathrm{~s}$, whose itinerary of shrines he has visited presupposes, Eamon Duffy notes, "at least a nodding acquaintance" with "a veritable gazetteer of sanctity", from Ireland to Palestine: 5

On the hills of Armony, where I see Noah's ark

With holy Job, and Saint George in Southwark;

At Waltham and at Walsingham,

And at the good Rood of Dagenham;

At Saint Cornelys; at Saint James in Gales,

And at Saint Winifred's Well in Wales;

At Our Lady of Boston; at Saint Edmondsbury,

And straight to Saint Patrick's Purgatory.

\footnotetext{
2 Diarmaid MacCulloch, Reformation: Europe's House Divided, 1490-1700 (London: Allen Lane, 2003), 18.

${ }^{3}$ Eamon Duffy, The Stripping of the Altars: Traditional Religion in England, 1400-1580 (New Haven: Yale University Press, 1992), 191; Walter Starkie, The Road to Santiago: Pilgrim s of St James (London: John Murray, 1957), 16, 60 \& 68-9.

${ }^{4}$ Fernand Braudel, The Mediterranean and the Mediterranean World in the Age of Philip II, trans. Siân Reynolds (2 vols., London: Collins, 1972), vol. 1, 217; Francois Lebrun, "The Two Reformations: Communal Devotion and Personal Piety," in A History of Private Life: The Passions of the Renaissance, ed. Roger Chartier, trans. Arthur Goldhammer (Cambridge, Mass.: Harvard University Press, 1989), 89; John Hale, The Civilization of Europe in the Renaissance (London: Harper Collins, 1993), 164.

${ }^{5}$ Duffy, op. cit. (note 3), 192
} 


\author{
At Rydyboe and at the Blood of Hales, \\ Where pilgrims' pains right much avails, \\ At Saint Davy's and Saint Denis; \\ At Saint Matthew and Saint Mark in Venice... \\ To these with other many one, \\ Devoutly have I prayed and gone, \\ Praying to them to pray for me \\ Unto the Blessed Trinity. ${ }^{6}$
}

"God save you, pilgrim! Whither are you bound? / To Saint Jaques le Grand" (III.v.32-4): when Helena next enters, after her "sainted vow" to walk to Spain, she is recognised as a pilgrim by the costume she wears until the final seconds of the play. As the Countess states, a happy ending now depends on the power to work miracles with the pilgrims' prayers "heaven delights to hear / And loves to grant" (III.iv.27-8). But even Catholic critics admit this scenario of "a pilgrimage to Spain, invocation of Saint James, penitential practice of walking barefoot," and prayers for intercession must have struck Protestants as perversely "Romish": 7 so much so the Arden editor thinks the idea Shakespeare takes it seriously is "too Popish to be probable". ${ }^{8}$ Yet it is precisely in terms of such perversity that Helena dedicates herself when she says her love for Count Bertram is such an "idolatrous fancy" that she "must sanctify his relics", since she is "Indian-like, / Religious in [her] error" (I.i.95, I.iii.199-200). Like the Indian boy in A Midsummer Night's Dream (II.i.124) or the "base Indian" of Othello (v.ii.356), this "Moorish" figure puns, Patricia Parker explains, on Catholics as the "tribe of (Thomas) More": the Tudor proto-martyr. ${ }^{9}$ And it suggests that, when Helena discloses how the medicine she practices as an inheritance has been "sanctified / By th'luckiest stars in heaven" (All's Well, I.iii.231-2), the "receipt" with which she cures the King of France of a lethal fistula has, in fact, been consecrated by "the great'st grace lending grace" (II.i.159) received in what must have been her father's own journey to Compostela. Stellar imagery reinforces this suggestion.

\footnotetext{
${ }^{6}$ John Heywood, The Plays of John Heywood, ed. Richard Axton and Peter Happe (Cambridge: Cambridge University Press, 1991), 112-13.

${ }^{7}$ David Beauregard, "Inspired merit': Shakespeare's theology of Grace in All's Well That Ends Well," Renascence, 51 (1999), 231.

${ }^{8}$ William Shakespeare, All's Well That Ends Well, ed. G. K. Hunter (London: Methuen 1959), 82.

${ }^{9}$ Patricia Parker, "What's in a Name and More," SederiXI: Revista de la Sociedad Espanola de Estudios Renascentistas Ingleses (Huelva: Universidad de Huelva, 2002), 101449, esp. 117.
} 
Thus, the play opens with the "poor physician's daughter" (II.iii.115) wishing for the Count as "a bright particular star" (I.i.81), but counting herself among the unlucky "Whose baser stars do shut us up in wishes" (170). And when, by healing the King, she rises enough for her "star" to reject her as a wife, she says she will "With true observance seek to eke out that / Wherein toward me my homely stars have failed / To equal my great fortune" (II.v.70-2). The clown Lavatch thinks she has been born under "a blazing star", however, and is "no puritan", but one who wears a "surplice of humility over the black gown of a big heart" (I.iii.76-84). And it is the pilgrim garb she in fact wears which makes us believe she will be one of those who, the braggart Parolles jests, "eat, speak, and move, under the influence of the most received star" (II.i.523); as she smiles how he was "born under a charitable star" (I.i.177). So, these pointers to "the most received", "charitable", "homely", "base", yet "sanctified", "blazing" and "luckiest" stars set Helena on the path to the "bright particular star" of Santiago, within one of those tall stories of miraculous healing told by the wayfarers themselves, as the old courtier Lafeu exclaims:

I have seen a medicine

That's able to breathe life in to a stone,

Quicken a rock, and make you dance canary

With sprightly fire and motion; whose simple touch

Is powerful to araise King Pepin, nay,

To give great Charlemagne a pen in's hand,

And write to her a love-line.

(II.i.70-6)

Shakespeare's pun on the hand of Charle-main, the liberator of Compostela from the Moors, according to the twelfth-century Book of St. James, connects his plot to those tales of chivalry with which the clerks of Cluny paved the Pilgrim's Way. And one cue for the play is, indeed, the yarn about Gerard of Roussillon who built the abbey of Vézelay, at the start of the Road, as penance for refusing a bride chosen by Charlemagne. ${ }^{10}$ There he enshrined relics of Mary Magdalene, who supposedly died at Marseilles: from where Helena returns as if from the dead. Other sources include a fable of a doctor's daughter, Christine of Pisano, who cured King Charles v; and Boccaccio's novella about Giletta, "a physician's daughter of Narbonne," who "healed the French

\footnotetext{
${ }^{10}$ William Shakespeare, All's Well That Ends Well, ed. Russell Fraser (Cambridge: Cambridge University Press, 1985), 6.
} 
king of a fistula". ${ }^{11}$ And in the background lies the Grail story of the Fisher King, hinted in that allusion to Pepin. But where these trails converge is in posing the problem put by the heroine to the dying king: namely, the pay-off for belief in an age "When miracles have by the greatest been denied" (II.i.139). As Julia Lupton writes in her study of Renaissance hagiography, Afterlives of the Saints, in scenes like this Shakespeare highlights aspects of his Catholic sources most offensive to Protestants, for while his rivals honoured the Anglocentric geography of the Elizabethan state, "the Europe of Shakespeare - his Venice, Verona, Navarre, Paris, Florence, as well as Vienna - is still a continent of pilgrimage routes, mapped by the motifs and scenarios of the late medieval legends of the saints". ${ }^{2}$ Thus, when Helena states that it were better "I met the ravin lion" than stay at home, "although / The air of paradise did fan the house / And angels officed all" (III.ii.11626), the narrative expectations she prompts by her quest are those of The Golden Legend. We are led to expect impossible returns, like the miracles of Our Lady of Rocamadour, who saw to it, we are told, that when the "man tormented by a fistula in his leg was taking his bandages off the ulcers that gnawed away at his muscles, he discovered nothing but scars and to his delight found he was cured." 13 This is a drama of "exceeding posting day and night" (v.i.1), which according to the crown of thorns its heroine says she welcomes (IV.iv.32), might well end in a miracle at the shrine of the saint. Yet historians show how soon Protestant distaste for any such "religious rite smacking of magic" came to divide English attitudes to Europe:

[So] it was the 'superstitious' character of popular devotion which most attracted the attention of English visitors to the Continent. [...] In South Germany peasants flocked to get water blessed by the image of St Francis Xavier as a preservative against the plague. In Rome it was the image of the Virgin Mary which drove away the pestilence. In Venice the inhabitants turned to St Rock. So long as it was possible for a Catholic prelate, like the Bishop of Quimper in 1620, to throw an agnus dei into a dangerous fire in hope of putting it out, the Roman Church could hardly

\footnotetext{
${ }^{11}$ William Painter, The Palace of Pleasure (London: 1566), quoted ibid., 7.

12 Julia Reinhard Lupton, Afterlives of the Saints: Hagiography, Typology, and Renaissance Literature (Stanford: Stanford University Press, 1996), 112.

${ }^{13}$ Marcus Bull (ed.), The Miracles of Our Lady of Rocamadour (Woodbridge: Boydell, 1999), 143.
} 
fail to retain the reputation of laying claim to special supernatural remedies for daily problem s. ${ }^{14}$

"How should I your true love know / From another one?" sings Ophelia, and gives an answer to rebuke Hamlet, who has come not from Compostela but Luther's Wittenberg: "By his cockle hat and staff, / And his sandal shoon" (Hamlet, IV.v.23-6). For those who did return from the "field of the star" - like the pilgrim buried in Worcester cathedral "with his staff and cockleshell by his side, his boots on his feet"; the fifteenth-century Sussex testator who left provision for five neighbours to go "to St James in Galicia"; the Suffolk parishioner who in 1501 donated to his church "scallops and other signs of St James"; or the London families of the $1560 \mathrm{~s}$ who still "cherished shells from Santiago as heirlooms passed from father to son"15 - seeing was believing and the act of faith in walking to Spain was rewarded by relics carried home. Dante, who famously likened the candlelit procession on the campus stellae to the Milky Way, wrote that "none are called pilgrims save those journeying to St James". ${ }^{16}$ So, the shells of Compostela became the best proof of the pilgrims' faith that miracles were secured when "the saints' aid was attained through exchange of gifts." In All's Well the "triple eye" Helena says her father gave her on his deathbed (II.i.103-5) may be just such a scallop. And back in England the contract was renewed each Feast of St James by the custom of decorating shrines with shells from Santiago which gave the date its popular name of Grotto Day. Thus, Londoners traditionally danced on this day at springs such as Camberwell or Clerkenwell and threw pennies into fountains they ornamented with shells. Folklorists have described the shell grottoes erected to collect money on July 25 by London children as late as 1900 as "the last faint memory of the great medieval pilgrimages to the shrine of St James". ${ }^{18}$ But shells are ancient talismans against the evil eye; and the aphrodisiac connotations of the story that Saint James's commemorate a bridegroom who rode in the sea on his horse to pull the saint's body

\footnotetext{
14 Keith Thomas, Religion and the Decline of Magic: Studies in Popular Beliefs in Sixteenth-and Seventeenth-Century England (Harmondsworth: Penguin, 1973), 84-5.

15 Duffy, op. cit. (note 3), 167 \& 193; Starkie, op. cit. (note 3), 71.

16 Dante, Vita Nuova, 40, Commentary on Sonnet XXIII, quoted ibid., 60 .

17 Beauregard, op. cit. (note 7), 231.

18 Christina Hole, A Dictionary of British Folk Customs (London: Paladin, 1978), 119; and English Custom and Usage (London: Batsford, 1942), 82.
} 
ashore, and returned to his bride covered in cockleshells, are perpetuated in the fertility rite of dropping coins in wishing-wells. ${ }^{19}$ Such was doubtless the symbolism when Shakespeare had a "fantastically dressed" Petruchio ride to wed Kate to a cockney rhyme: "Nay, by Saint Jamy, / I hold you a penny, / A horse and a man / Is more than one" (Shrew, III.ii.74-8). It can be no accident, therefore, that James is the male saint with most well-dedications in Britain. Nor, for a play about "holy wishes" which starts with Helena's joke: "I wish well... That wishing well had not a body in it" (I.i.52; 166-8), can it be incidental to All's Well that the largest number of all well-dedications is to the Yorkshire mother of Emperor Constantine, who united Britain and Rome, the first English pilgrim, Saint Helena herself. ${ }^{20}$

It was the London hospital devoted to the waters of the saint which gave the English court its title, when a royal palace was built over the spring, of the Court of St James, and for centuries English kings sponsored the well-cult as their own. ${ }^{21}$ Even in the $1530 \mathrm{~s}$ Henry VIII went on pilgrimage to the well of Our Lady at Walsingham, trudging barefoot the last few miles. ${ }^{22}$ As Keith Thomas details in Religion and the Decline of Magic, after such patronage the wells that lined the pilgrim routes became covers for Catholic resistance in Reformation England since they "retained semi-magical associations, even though Protestants preferred to regard them as medicinal springs working by natural means." 23 Thus, Mary Queen of Scots turned the Derbyshire well at Buxton into a Mecca for recusants when she drank the water there nine times during her captivity; and Bath was developed in the 1590 s by the clique of Catholic gentry who "met at the Bath" to plan the Gunpowder Plot. ${ }^{24}$ In fact, the Elizabethan regime only lifted a 1539 ban on drinking mineral-waters because of the exodus of dissidents to Spa in the Spanish Netherlands under pretext of taking cures. A starting-point for the Grand Tour, Spa remained "a centre of Catholic intrigue" that "the English government kept under

\footnotetext{
${ }^{19}$ Horton and Marie-Hélène Davies, Holy Days and Holidays: The Medieval Pilgrimage to Compostela (Lewisburg: Bucknell University Press, 1982), 21-20.

20 James Rattue, The Living Stream: Holy Wells in Historical Context (Woodbridge: Boydell, 1995), 70-1.

${ }^{21}$ Edwin Mullins, The Pilgrimage to Santiago (London: Secker \& Warburg, 1974), 64.

${ }^{22}$ Francis Jones, The Holy Wells of Wales (Cardiff: University of Wales Press, 1954), 58.

23 Thomas, op. cit. (note 14), 80.

24 Phyllis Hembry, The English Spa, 1560-1815: A Social History (London: Athlone Press, 1990), $22-4 \& 33$.
} 
strict surveillance" in the reign of James I, its colony of exiles quaffing Spa-water as an act of faith as much as health. ${ }^{25}$ So, given that "wells were, for the Establishment, associated with the Catholic past and now masked recusant plots," 26 it is telling that in All's Well the heroine should equivocate about the magical or natural origin of the "something" added to the remedy she gives the King, hinting only that "Great floods have flown from simple sources" (II.i.137). The chant to which she works the miracle specifies, however, that "Ere twice in murk and occidental damp / Moist Hesperus hath quenched her flame... Health shall live free" (162-7), and this invocation of sunset over western waters may indicate a subterranean source for the secret ingredient in the most westerly of British springs: St Winifred's or Holy Well in Wales. In the $1600 \mathrm{~s}$ this Flintshire well remained the most popular devotional site in Britain, and the authorities were unable to stop "daily disorders around St. Winifred's Well" of "the confused multitudes" going on "superstitious pilgrimage by pretending that the waters are beneficial". 27 In 1629 a spy at the scene reported that "Papists and priests assembled on St. Winifred's Day" comprised "knights, ladies, gentlemen and gentlewomen of diverse countries to the number of 1,500". ${ }^{28}$ And we can infer the dramatist took an interest in such pilgrimages, because among those who travelled to the shrine beside the Irish Sea and adopted Winifred as a patron saint according to the Jesuit "Testament" he signed in 1580 - was Shakespeare's father John. ${ }^{29}$

When Bertram forsakes Helena for Diana he calls her "Fontibell" (IV.ii.1): the name of the public fountain in London that featured a statue of Diana. But as G. K. Hunter asks, "Why should Bertram give his beloved the name of a fountain?"30 The answer may be that All's Well has the programme of St James's Day and centres on a wish. Thus, when the King and Helena enter dancing, after her "physic" cures him of the disease "the most learned doctors" supposed "labouring art [could] never ransom" (II.i.114), the wishing-game they

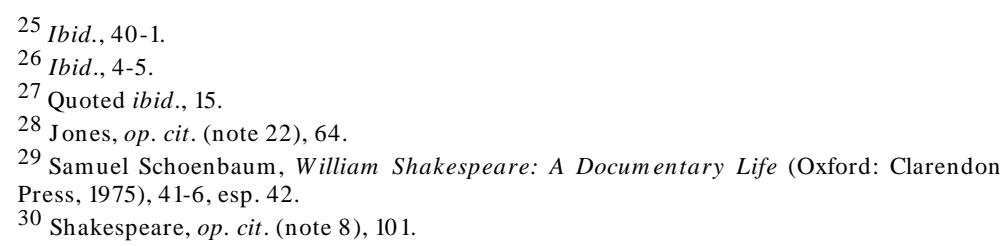


begin does follow the scenario of a Stuart pilgrimage, where magic coexisted with tourism, and as Lafeu exalts, the confusion of "the learned and authentic Fellows" allowed the "hand of heaven" to be credited (II.iii.12-31). Sceptics such as Camden were bemused when chemistry confirmed the curative power of waters "famous in old wives' fables". ${ }^{31}$ But Shakespeare's play takes place precisely in the space opened up by this embarrassment, when the Catholic Queens Anne and Henrietta Maria led the devotees of Buxton and Bath, and those "ensconcing" themselves "in seeming knowledge" learned to be "Generally thankful" for such popish practices (38). ${ }^{32}$ So, with her pilgrim's bottle, Helena inhabits the same world as matrons who carried around flasks of holy water, even if she disavows "water in which relics were powdered or immersed". ${ }^{33}$ Her wish that her wishing-well "had not a body in it" seems aimed, in fact, at those Catholic zealots who dispensed water fortified with saints' blood, and prepares for the surprise when "Doctor She" (II.i.77) does not have a wish come true. For with each of her icy suitors given a wish by "Her that so wishes" (II.iii.83), this well-wishing is meant to mix her "merit", as Lafeu quips, with the "one grape" whose "father drank wine": as a Catholic, presumably, before the son lapsed (95). Queen Elizabeth thought wine diluted in holy water a joke, and goaded Leicester to sip his "with as much sacred water" from Buxton "as he lusteth to drink". 34 But The Faerie Queene spelled out the Eucharistic implications by telling how the "well of life" flowed with Reformation "virtues and med'cine good", like Bath or Spa, until the "Dragon defiled those sacred waves" with blood. ${ }^{35}$ Helena's wish to marry Bertram, the King therefore explains, will dilute such differences, since "our bloods, / Of colour, weight, and heat, poured all together, / Would quite confound distinction" (II.iii.114-16). In Shakespeare's Tribe Jeffrey Knapp argues the dramatist aimed himself to "unite audiences" in the ecumenical spirit with which Lavatch would like to knock together the heads of

\footnotetext{
${ }^{31}$ Rattue, op. cit. (note 20), 114-15.

32 Hembry, op. cit. (note 24), 33,39-40, 45-7 \& 58-61.

33 Carole Rawcliffe, "Pilgrimage and the sick in medieval East Anglia," in Colin Morris and Peter Roberts (eds.), Pilgrimage: The English Experience from Necket to Bunyan (Cambridge: Cambridge University Press, 2002), 121, 131\& 136.

34 Quoted Reginald Lennard, Englishmen at Rest and Play: Some Phases of English Leisure, 1558-1714 (Oxford: Clarendon Press, 1931), 9.

35 Edmund Spenser, The Faerie Queene, I.xi.29-30, ed. A. C. Hamilton (London: Longman, 1977), 149.
} 
"young Chairebonne the puritan and old Poisson the papist... like any deer i'th'herd" (I.iii.45-7). ${ }^{36}$ It is possible to see in Bertram the portrait of just such a headstrong young Puritan. But when the absolutist King imposes marriage on the "proud, scornful boy" (II.iii.151), the "recantation" (186) is as forced as the response to any real decrees of religious toleration, like the recent Edict of Nantes:

Good fortune and the favour of the King Smile upon this contract, whose ceremony Shall seem expedient on the now-born brief, And be performed tonight. The solemn feast Shall more attend upon the coming space, Expecting absent friends. As thou lov'st her Thy love's to me religious; else, does err.

(II.iii.173-9)

On the "not coincidental" St James's Day 1603, King James walked from St James's Palace for an "expedient" coronation service, with "all show and pomp omitted" due to plague. Outside the Abbey, "rain poured down on triumphal arches Londoners had begun to build" for a procession now postponed, and the king "lost no time retreating to uninfected air. That week 1,103 persons died of plague". 37 So, instead of London's Fountain of Diana running wine, the Jacobean age was inaugurated with wells dressed in St James's shells, which that year must have truly been intended to repel bad luck. And it was in this hiatus of "coming space", with the "solemn feast" delayed until March 1604, "Expecting absent friends," that editors infer the only one of Shakespeare's comedies to open with a funeral was staged. After the funerals, the season of All's Well was, in fact, a unique period of wellwishing in London, when the king suspended anti-Catholic fines, peace with Spain was proclaimed, and the court did wait upon absent friends, in the form of an embassy from Madrid. Recent research locates Shakespeare in the patronage-network of those crypto-Catholic English nobles who themselves received pensions from Philip III and had most to gain from the Edict of Toleration they hoped could be extracted from

\footnotetext{
36 Jeffrey Knapp, Shakespeare's Tribe: Church, Nation, and Theater in Renaissance England (Chicago: Chicago University Press, 2002), 53 \& 169.

${ }^{37}$ David Cressy, Bonfires and Bells: National Memory and the Protestant Calendar in Elizabethan and Stuart England (Berkeley: University of California Press, 1989), 57; A. P. V. Akrigg, Jacobean Pageant: The Court of King James I (London: Hamish Hamilton, 1962), 29-30.
} 
James (who had, after all, been baptised in Catholic rites). ${ }^{38}$ With Spanish gold behind them, nothing was therefore more apt than that the new King's Men should stage a play set on the Jacobean Road to Spain which hangs on promises, like those of Bertram, to admit "The great prerogative and rite of love" in "due time... Whose want and whose delay is strew'd with sweets / Which they distil now in the curbed time, / To make the coming hour o'erflow with joy / And pleasure drown the brim" (II.iv.38-44). Nor should that anxiety in this comedy be aroused by the prospect of a "deadly divorce" (v.iii.312) if the shotgun marriage is prevented and the pilgrim goes her own way. Feminists notice how Helena conforms to the type of female "holy anorexic" whose "superhuman fasts and vigils" challenged patriarchy in the post-Reformation Church. ${ }^{39}$ Holy wells, like Shakespeare's local one at Shottery which "cured women's complaints", were always "a women's preserve". ${ }^{40}$ But in All's Well, as the Countess warns, happiness hinges on the hope that Helena "will speed her foot" back from her devotions (III.iv.37), before she really does end up as the saint she is reported to have become in Spain:

Sir, his wife some two months since fled from his house. Her pretence is a pilgrimage to Saint Jaques le Grand; which holy undertaking with most austere sanctimony she accomplish'd; and there residing, the tenderness of her nature became as a prey to her grief; in fine, made a groan of her last breath, and now she sings in heaven. (IV.iii.45-51)

Helena's "Life" as a saint, verified "by her own letters, making her story true even to the point of her death," and her beatific "death itself," which since it "could not be her office to say is come" is "faithfully confirmed by the rector," no less, of Santiago (52-6), is a fiction that echoes the expectations of a generation of English Catholics who let their daughters disappear into the convents of Toledo and Madrid. Shakespeare's daughters were both unmarried at this time, when English "Poor Clares" were also recruiting for a new convent at SaintOmer; and Susanna would shortly be listed as a "popishly affected"

38 John Finnis and Patrick Martin, “Another Turn for the Turtle: Shakespeare's Intercession for Love's Martyr," Times Literary Supplement, 18 April 2003, 12-14; Caroline Bingham, James VI of Scotland (London: Weidenfeld \& Nicolson, 1979), 22.

${ }^{39}$ See Rudolph M. Bell, Holy Anorexia (Chicago: Chicago University Press, 1985), 122 \& 151-79.

${ }^{40}$ Rattue, op. cit. (note 20$), 95$. 
recusant. ${ }^{41}$ So, in his next comedy, Measure for Measure, the writer would test the conventual vocation still more intensely, by having Isabella take her vows in Vienna among the "votarists of Saint Clare" (I.iv.5). There even Lucio pays lip-service to one "enskied and sainted" by her "renouncement" (33). In fact, no other English dramatist accords anything near the respect given by Shakespeare to those who "endure the livery of a nun / For aye to be in shady cloister mewed," and whose "maiden pilgrimage" he has Theseus salute (Dream, I.i.705). In Troilus and Cressida, for instance, it is Hector's awe at the "high strains / Of divination" in Cassandra which overrules Troilus's contempt for a "foolish, dreaming superstitious girl" (II.ii.112, v.iii.82). And Hamlet's order to "Get thee to a nunnery" (Hamlet, III.i.122), is purged in Pericles by Mariana's purification of the brothel and prayers beside the "maiden priests" of "Diana's altar" (v.i.226, v.ii.37). This "votress" is given a curriculum vitae, indeed, to make her an exemplar of the life among those sisters in Flanders or Spain which may have tempted the Shakespeare girls, as "She sings like one immortal", dances "goddess-like", composes "admired" hymns, and teaches needlework so ardently "That pupils lacks she none" (v.0.3-11). So feminists who assume that Shakespeare shared Puritan disgust at the decision of those, like Olivia, who wall themselves in chantries, ignore the irony that he gives the stock Reformation critique of virginity to the rogue Parolles (I.i.116-50). ${ }^{42}$ They forget that what makes his image of monastic life so unlike that of his rivals is the "return effect" in his dramas between society and the convent, meaning that if the cloister is tested in them by the world, the world is also tested by the cloister. So, it comes as no surprise that in 1619 Pericles was catalogued as the only secular text taught at Saint-Omer; or that in the 1640s the Second Folio

\footnotetext{
${ }^{41}$ See May Winefride Sturman, "Gravelines and the English Poor Clares," London Recusant, 7 (1977), 1-8. See also A. C. F. Beales, Education Under Penalty: English Catholic Education from the Reformation to the Fall of James II (London: Athlone Press, 1963), 203-4; Patricia Crawford, Women and Religion in England, 1500-1700 (London: Routledge, 1992), 85; and Marie Rowlands, "Recusant Women, 1540-1640," in Mary Prior (ed.), Women in English Society, 1500-1800 (London: Routledge, 1985), 168-74, esp. 169. For Susanna Shakespeare's listing as a recusant on May 51606 , see Hugh Hanley, "Shakespeare's Family in Stratford Records," Times Literary Supplement, 21 May 1964, 441: the records are in the Act Books of Kent County Records Office, via the Sackville papers.

${ }^{42}$ See, in particular, Juliet Dusinberre, Shakespeare and the Nature of Women (Basingstoke: Macmillan, 1996), 5-7 and 30-51.
} 
was on the Jesuit syllabus at Valladolid. ${ }^{43}$ The Europe of the CounterReformation evidently took this English dramatist seriously. And he returned the compliment, projecting the forbidden continent of seminaries and pilgrimages as a possibility in play after play, where the end always draws towards some virtual shrine, like the pilgrim's tomb of cockleshells which Pericles imagines for Thaisa:

a monument upon thy bones

And aye-remaining lamps...

Lying with simple shells.

(Pericles, III.i.60-3)

In All's Well, Helena's death in Santiago is reported to her husband as the truth, with "the particular confirmations, point from point, to the full arming of the verity" (IV.iii.60). The audience knows, however, that this is yet another pious tale, and that instead of plodding, as she pretends, from France to Spain, the heroine has turned up in Florence, where she changes direction again and introduces herself to the Widow as one of the "palmers" (so-called from palms they carried) coming from Jerusalem (III.v.35). Critics have long fretted over this false-turning, starting with Dr. Johnson, who dryly remarked that the Tuscan city "was somewhat out of the road from Rousillon to Compostela". ${ }^{44}$ Helena's trip to Italy looks like an instance of Shakespeare's ignorance; or of the gap between European fact and English fiction which, Manfred Pfister objects, traps criticism in "a law of diminishing returns", whereby "the more information scholars gather" concerning Europe, "the less this knowledge yields new in sights into the plays" them selves..$^{45}$ Helena has, however, travelled to Florence to shadow Bertram. And her detour also fulfils her mother-inlaw's wish to have "diverted her intents". So, it is very much to the point that in Shakespeare's next play, Othello, the "young and sweating devil" Iago (III.iv.40) carries a name that associates him expressly with the road to Compostela, and the most militant face of St James, as

\footnotetext{
${ }^{43}$ Willem Schrickx, "Pericles in a Book-List of 1619 from the English Jesuit Mission and Some of the Play's Special Problems," Shakespeare Survey, 29 (Cambridge: Cambridge University Press, 1976), 21-32.

${ }^{44}$ Quoted in William Shakespeare, op. cit. (note 10), 6.

45 Manfred Pfister, "Shakespeare and Italy, or, the law of diminishing returns," in Michelle Marrapodi, A. J. Hoenselaars, Marcello Cappuzzo and L. Falzon Santucci (eds.), Shakespeare's Italy: Functions of Italian Locations in Renaissance Drama (Manchester: Manchester University Press, 1997), 296.
} 
defender of Christendom and slayer of the Moors. ${ }^{46}$ Iago has been interpreted by some as a caricature of Jesuit conspiracy; and it was indeed the cult of the warrior saint as Santiago Matamoros that fired his Basque countryman, the maimed soldier and Jesuit founder, Inigo de Loyola. ${ }^{47}$ Othello can be read as an allegory, therefore, of the incitement by Jesuits of the English "tribe of More"; and the perversion of what the Moor calls his "pilgrimage" (I.iii.152) into paranoia over a handkerchief as figuring the foolishness of the "Spanish faction" of politicised Catholics, who put their faith in the bloody relics of the saints. ${ }^{48}$ So, this tragedy confirms why the comedy could never end in Santiago. All's Well turns away from the Pyrenees to disavow the ultramontanes. In a London that would applaud Middleton's Hispanophobic Game at Chess, what is remarkable, however, is not that Helena shies away from Spain, but how long she keeps up her "pretence" of being one of the "enjoin'd penitents... To Great Saint Jaques bound" (III.v.93), and has those who mourn for her believe that her "incensing relics" are buried at Compostela (v.iii.25). Most startling of all is how the uncanniness of her pretended return from Spain, when she does reappear from "oblivion" at the end (24), is viewed by the King as a Jesuit plot, one of the exorcisms that made the Society of Jesus so feared:

$$
\begin{aligned}
& \text { KING. Is there no exorcist } \\
& \text { Beguiles the truer office of mine eyes? } \\
& \text { Is't real I see? } \\
& \text { HELENA. No, good my lord; } \\
& \text { 'Tis but the shadow of a wife you see... }
\end{aligned}
$$

"Who cannot be crushed with a plot?" (IV.iii.301): Parolles' response to his entrapment as a spy is a question that also casts doubt on the Jesuitical trick with which Helena corners the Count. Thus, in his essay, "King Lear and the Exorcists," Stephen Greenblatt writes that by the time of All's Well "Shakespeare had marked out exorcisms as

\footnotetext{
${ }^{46}$ See Barbara Everett, "Spanish Othello: the Making of Shakespeare's Moor," Shakespeare Survey, 35 (Cambridge: Cambridge University Press, 1982), 103.

${ }^{47}$ See Robert Watson, "Othello as Protestant Propaganda," in Claire McEachern and Debora Shuger (eds.), Religion and Culture in Renaissance England (Cambridge: Cambridge University Press, 1997), 234-57.

${ }^{48}$ See Richard Wilson, "Dyed in Mummy: Othello and the Mulberries," in Secret Shakespeare: Studies in theatre, religion and resistance (Manchester: Manchester University Press, 2004), 155-85.
} 
frauds", and presented such rituals as "popish impostures" which "have been emptied out". ${ }^{49}$ Yet this is arguably to side too much with those "philosophical persons" who, in the terms of the play, "say miracles are past," and "make modern and familiar things supernatural and causeless," making "trifles of terrors," when they "should submit... to an unknown fear" (II.iii.1-5). It is to overlook how Shakespeare toasts "absent friends" at this instant of rapprochement with Catholic Europe and even meets them in their faith half way. The audience knows Helena's pilgrimage to Santiago is a traveller's tale. And they can see that, far from dying a martyr, "she feels her young one kick" (v.iii.299) from bedding Bertram. But the end depends on her husband believing he has killed his wife, and confessing "high-repented blames" (37). So, like the statue of Hermione by "that rare Italian master" Giulio Romano (Winter's Tale, v.ii.87), Helena's incense-laden tomb at Compostela is a piece of Catholic illusionism round which happiness revolves. In Henry VIII Shakespeare sets such fictions in historical context, when Catherine of Aragon dreams of "spirits of peace" who visit her from her "friends in Spain" and her father, the King of Spain, who was, we are assured, "The wisest prince that there had reigned" (II.iv.46-53, IV.ii.83). "My friends, / They that my trust must grow to, live not here," grieves the Queen in Shakespeare's play, "They are (as all my other comforts) far from hence / In mine own country" (III.i.8791), but she dies in the arms of an envoy of her nephew, Charles v. Habsburg Europe, the Europe of holy wells and pilgrimage roads, remained under erasure on Shakespeare's stage. But no English dramatist was ever so open as this one to the return of the repressed from the enemy side. It may not be chance, therefore, that the first recorded purchaser of the 1623 Folio was the Spanish ambassador, Count Gondomar. ${ }^{50}$ For the attitude Shakespeare gave Navarre in Love's Labour's Lost defines an entire dramatic practice, when the king says that the stories Don Armado tells about the martyrs of "tawny Spain" are so "enchanting" to the man himself that it does not seem to matter whether they are true or false:

\footnotetext{
${ }^{49}$ Stephen Greenblatt, Shakespearean Negotiations: The Circulation of Social Energy in Renaissance England (Oxford: Clarendon Press, 1988), 114 \& 119.

${ }^{50}$ See Gary Taylor, "Forms of Opposition: Shakespeare and Middleton," English Literary Renaissance, 24 (1994), 315.
} 
How you delight, my lords, I know not, I;

But I protest I love to hear him lie,

And I will use him for my minstrelsy.

(I.i.160-74)

"Yes, I have gained my experience": in As You Like It, the traveller who has brought back no more than the biscuit he says is all that is left after a voyage, is not called Jaques for nothing. As editors note, his name plays on "jakes", the word for toilet. And the pun suggests his experience has been that of a tourist in an age when the waters of Saint Jaques have indeed been turned from holy wells to drains. With his Spaniolated melancholy, Jaques has returned from Santiago, Rosalind sighs, with only the experience to make him sad: "to have seen much and to have nothing is to have rich eyes and poor hands... and to travel for it too!" (II.vii.39, IV.i.10-26). The very name Jaques thus sums up English disenchantment with Europe when the pilgrimage network that centred on Compostela was disrupted as, in the words of the Reformers, "a forsaking of the Fountain of living waters, to go to a broken Cistern." 51 For Londoners the breach had been celebrated in 1589 when Drake landed in Spain "intent on destroying Santiago, the heart of "pernicious superstition'." 52 On that occasion the saint's relics were saved from English vandals by being buried. But Shakespeare reflected such iconoclasm in showing the most famous English traveller to Compostela, John of Gaunt, as one whose idea of true chivalry is to be "feared" as far as "the sepulchre, in stubborn Jewry" (Richard II, II.i.52-5). Similarly, by setting Henry IV's death in the "Jerusalem Chamber" of Westminster rather than the Holy Land he troped Erasmus' joke that there was no point going abroad if you could be a pilgrim in your own living room. ${ }^{53}$ Such was the Reformation cliché attested by Raleigh, when he preferred his "Scallop shell of quiet" and "Bottle of salvation" to any European pilgrimage. ${ }^{54}$ Tudor minds had been set in this frame by the physician and ex-monk Andrew Boorde, when he reported that not only was there "not one ear

\footnotetext{
51 Thomas Hall, Flora Floralia; Or, the Downfall of the May Games (London: 1661), quoted op. cit. (note 13), 105-6.

52 Starkie, op. cit. (note 3), 58 .

53 Erasmus, The Colloquies, trans. C. Thompson (Oxford: Oxford University Press, 1964), 312, quoted in Wes Williams, Pilgrimages and Narrative in the French Renaissance: The Undiscovered Counrty'(Oxford: Clarendon Press, 1998), 128-9.

54 Sir Walter Raleigh, "The Passionate Man's Pilgrimage," in The Poems of Sir Walter Raleigh, ed. Agnes Latham (London: Routledge \& Kegan Paul, 1951), 49.
} 
or bone of St James in Compostela," but the wells there were so polluted nine of his compatriots died after drinking from them. ${ }^{55}$ And Shakespeare may have read this "modern and familiar" satire while writing All's Well, if Boorde's work stood on the shelf of his fellowgraduate of Montpellier, Doctor John Hall, who settled in Stratford in 1601. Perhaps Hall was one reason why, in this comedy of medicine and magic, the heroine goes towards Huguenot Montpellier rather than Catholic Compostela, since within two years the Puritan doctor would marry the dramatist's "popish" daughter, Susanna. Though the Gunpowder Plotters would make one last pilgrimage from Stratford to St Winifred's Well to pray for England to be reunited with Catholic Europe, it might have seemed to the author of All's Well That Ends Well that the well belonged to all, so this wishing-well was well-ended with his daughter's swelling.

Richard WILSON

University of Lancaster

55 Andrew Boorde, The First Book of the Introduction of Knowledge, ed. James Hogg (Salzburg: Universitat Salzburg, 1979), 9 \& 87-8. 